\title{
Diversity of mammals in forest patches of Cisokan, Cianjur, West Java, Indonesia
}

\author{
TEGUH HUSODO ${ }^{1,2,3}$, PUPUT FEBRIANTO ${ }^{2,3, \varphi}$, ERRI NOVIAR MEGANTARA ${ }^{1,2,3}$, SYA SYA SHANIDA $^{3}$, \\ MUHAMMAD PAHLA PUJIANTO ${ }^{3}$ \\ ${ }^{1}$ Department of Biology, Faculty of Mathematics and Natural Sciences, Universitas Padjadjaran. J1. Raya Bandung-Sumedang Km 21, Jatinangor, \\ Sumedang 45363, West Java, Indonesia. Tel. +62-22-7796412 ext. 104, Fax. +62-22-7794545. `email: puput.febrianto01 @ gmail.com \\ ${ }^{2}$ Program of Environmental Science, School of Graduates, Universitas Padjadjaran. J1. Sekeloa, Coblong, Bandung 40134, West Java, Indonesia. \\ ${ }^{3}$ Institute of Ecology, Directorate of Research, Community Services and Innovation, Universitas Padjadjaran. Jl. Raya Jatinangor Km 21, Sumedang \\ 45363, West Java, Indonesia
}

Manuscript received: 3 July 2018. Revision accepted: 20 April 2019.

\begin{abstract}
Husodo T, Febrianto P, Megantara EN, Shanida SS, Pujianto MP. 2019. Diversity of mammals in forest patches of Cisokan, Cianjur, West Java, Indonesia. Biodiversitas 20: 1281-1288. Most species on Java, Indonesia are ecologically associated with or dependent on forests, the island's high deforestation rates are a major threat to its species. Until now, various efforts to conserve mammals are still focused on natural ecosystems, such as forests. There has not been much research on mammals carried out specifically in non-conservation forest areas, whereas many regions in Indonesia have extensive community lands in the landscape and are directed to be areas that have a conservation function, besides still functioning as a production system. Therefore, it is necessary to examine the diversity of mammals that are still found in Cisokan especially those that have high conservation status and their habitat. Combination of several research methods applied, such as semi-structured interview, sign survey, direct observation, camera trapping, and collapsible trap. Mammalian diversity in the Cisokan forest patched is found in 26 species and among them are endangered species, such as Javan Leopard, Pangolin, and Slow Loris. These three species occupy diverse land cover from natural forest to human lands, such as production forests, settlements, rice fields, and agroforestry or mixed gardens. The existence of these species on human land has the potential for human-wildlife conflict, so it needs to be studied further in wildlife management in Cisokan.
\end{abstract}

Keywords: Cisokan, forest patched, mammalia

\section{INTRODUCTION}

Most species on Java are ecologically associated with or dependent on forests, the island's high deforestation rates are a major threat to its species (Meijaard and Pene 2014). The high rate of deforestation is partly due to the high level of human expansion into the natural habitat of wildlife. This is often caused by population growth and economic factors, thus triggering the occurrence of encroachment activities, land conversion, hunting, and wildlife trading (Sulistyadi 2016). At present, only about 1.1 million hectares of forest remain in Java (Prasetyo et al. 2013), covering around 7\% of the land area. The activity of forest encroachment and land conversion produced forest patch. It is assumed that there are still animals that have REEPS status (Rare, Endangered, Endemic and Protected Species) in the forest patch. The high anthropogenic factors carried out continuously without any act of conservation in the forest area will threaten the animals inside the forest patch.

In addition, collection and hunting pressure is also high. The Javan Tiger became extinct in the 1960s and the Javan Rhino is nearly extinct with only some 40 animals remaining in the world. Mammal species, such as pangolins highly valued for the medicinal trade and increasingly rare in the wild. Thus, there are few forests on Java that remain pristine and with a complete fauna (Meijaard and Pene
2014). One of the locations on Java that has high biodiversity is in Cisokan as a non-conservation forest area. Of the animals found so far in Cisokan, several mammals are of immediate global conservation concern with two species, the Javan Slow Loris and the Javan Leopard being considered Critically Endangered on the IUCN Red List of Threatened Species. This means that they are facing an extremely high risk of extinction in the wild (Meijaard and Pene 2014).

Until now, various efforts to conserve mammals are still focused on natural ecosystems, such as forests. There has not been much research on mammals carried out specifically in non-conservation forest areas, whereas many regions in Indonesia have extensive community lands in the landscape and are directed to be areas that have a conservation function, besides still functioning as a production system. Therefore, it is necessary to examine the diversity of mammals that are still found in Cisokan especially those that have high conservation status and their habitat.

Previous studies of biodiversity have been conducted in the Cisokan area, such as ANDAL-PT. PLN (2007); Rahmat (2009); LIPI (2011, 2012); and UNPAD (2014a). In 2017, this research was conducted to determine the latest condition of mammals by using a combination of several research methods, so that expected information related to the mammal species can be more comprehensive. 


\section{MATERIALS AND METHODS}

\section{Study area}

Cisokan located on the border between West Bandung and Cianjur. The location area is $775.6 \mathrm{Ha}$ and this area has hilly contours and steep slopes with altitude 400-1000 m asl. Cisokan area is part of the Southern mountainous in West Java (Meijaard and Pene 2014). This geographic condition causes still preserved biodiversity of flora and fauna. A total of 15 sampling sites were selected based on interview and desk study (Figure 1).

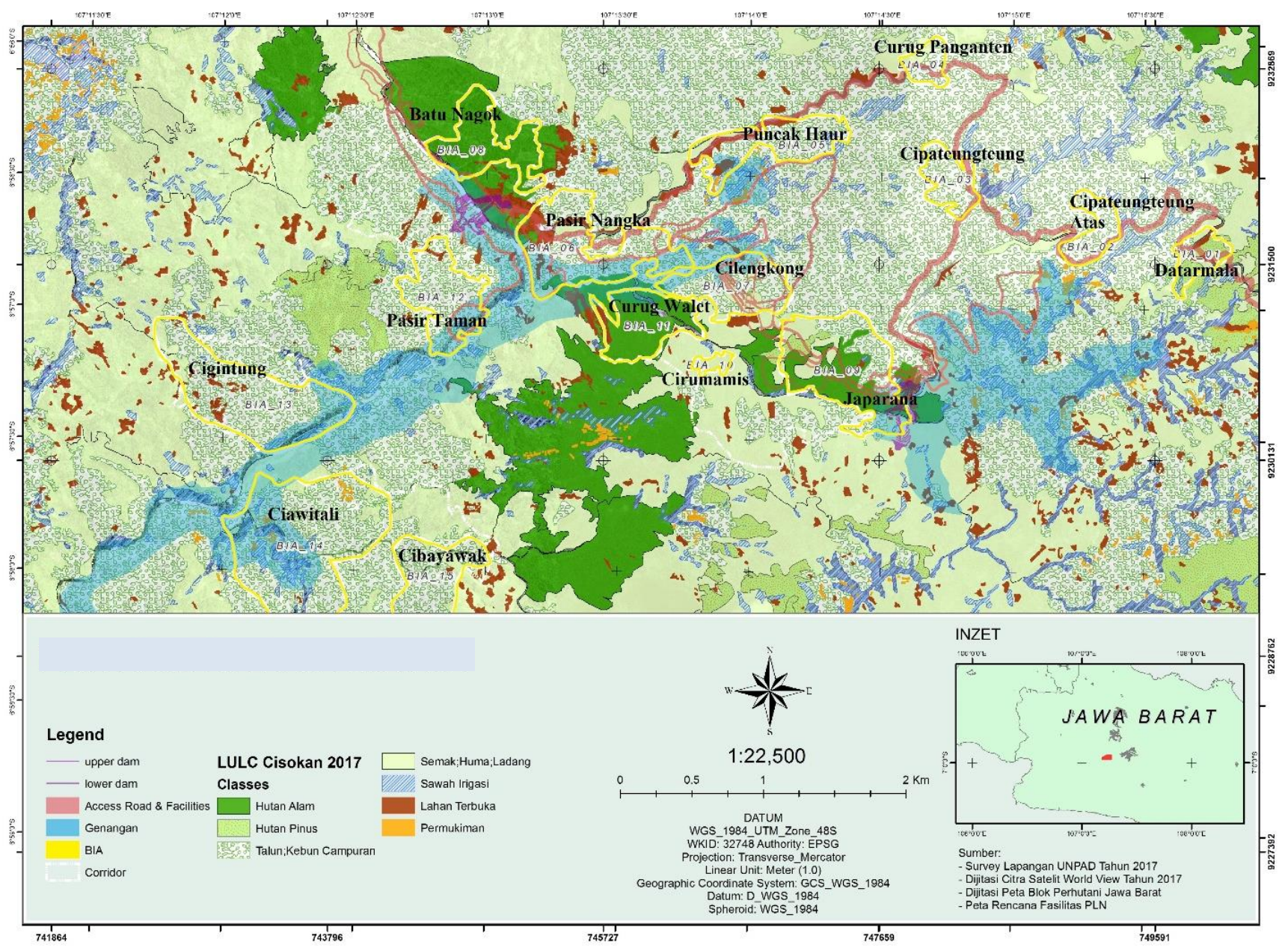

Figure 1. Location of the 15 sampling sites at Cisokan, West Java, Indonesia

Table 1. Description of the 15 sampling sites at Cisokan, West Java, Indonesia (Meijaard and Pene 2014)

\begin{tabular}{lll}
\hline Area name & Area & Land cover types \\
\hline Datarmala & 10 ha & Production forest of Rasamala, pine, shrubs, and banana. \\
Cipateungteung Atas & 12,39 ha & Pine production forest, shrubs, and talun or mixed garden with many planted palm tree. \\
Cipateungteung & 13,10 ha & Mixed garden/ talun, dominant plant of bamboo and palm. \\
Curug Panganten & 7,80 ha & Pine forest, calliandra, umbrella tree, shrubs, and agroforestry with bamboo and palm. \\
Puncak Haur & 15,50 ha & Calliandra tree, shrubs, and agroforestry. \\
Pasir Nangka & 44,65 ha & Agroforestry, shrubs and natural forest. Among these areas is albasiah production forest. \\
Cilengkong & 25,95 ha & Agroforestry planted banana, palm, pine production forest, and shrubs. \\
Batu Nagok & 26,62 ha & Natural forest. \\
Japarana & 48,10 ha & Pine forest, shrubs, and agroforestry. \\
Curug Cirumamis & 2,84 ha & Natural forest in the edge of Cirumamis River and the top of the river cover with pine forest and shrubs \\
Curug Walet & 24,75 ha & Natural forest with quite dense tree canopy. \\
Pasir Taman & 27,94 ha & Teak forest, shrubs, and agroforestry \\
Cigintung & 55,98 ha & Agroforestry. \\
Ciawitali & 78,26 ha & Pine forest, shrubs, agroforestry with dominant plant of bamboo and palm \\
Cibayawak & 30,69 ha & Natural forest (remnant forest) in the top of the river, pine forest, shrubs, and agroforestry \\
\hline
\end{tabular}


Cisokan consist of various land cover types, including natural forests/ remnant forest, production forests/ Perhutani forests (pine, teak, or Altingia excelsa), riparians, mixed gardens or agroforestry (locally named talun), shrubs, huma or swidden farming or slash and burn cultivations that make up agricultural fields on slopes, irrigation rice fields, open fields, and settlements. The description and detail of land cover types at each sampling site in Cisokan can be seen in Table 1 and Figure 1.

\section{Procedures}

The data collection technique in this study was conducted by qualitative methods by combining several methods, such as direct observation, camera trapping, and collapsible traps, semi-structured interviews, and sign surveys. Observations were made on mammals, except for bats, because no special research methods for bats were carried out.

\section{Semi-structured interview}

The semi-structured interview aims to identify potential sites as the habitat and existence of mammals in Cisokan. Questions are prepared first in the form of interview guidelines and the other questions can appear naturally or spontaneously during conversations with informants (Iskandar 2012). Informants were selected by the snowball sampling technique. According to Iskandar (2012), informants were selected purposively based on their competencies rather than representative populations, considering the diversity (triangulation) based on existing categorizations. The categorization of informants in this study was hunters, community elders, and buffalo herders, and farmers. A main or key informant was chosen from all informants to collaborate more actively in research and was chosen using criteria set by the researcher (Albuquerque et al. 2014).

\section{Sign survey}

Sign surveys intended to find the existence of animals based on signs of existence that left in nature (Boitani and Powell, 2012). Any sign of mammal species found, either directly or indirectly (feces, tracks, hair/thorn e.g. porcupine, and nest) are recorded about species, number, and location of the sign (Fragoso et al. 2016). In addition, leftover and scratch of carnivore species should be recorded. Various signs of mammals existence that was found should be measured and were documented. According to Raharyono and Paripurno (2001) that if footprints are found, it is necessary to observe how far the signs are left behind. Searching for signs of animal's existence is traced to the pathway, under a large tree, splitting a banquet root, or on a flat rock that tends to be protected or hidden (Raharyono and Paripurno 2001). In addition, it is also done on the banks of rivers and large rocks, paddy fields, and holes between rocks.

According to Raharyono and Paripurno (2001) that the search for tracks is traced to the pathway. When finding footprints, measurements of the length, width, and depth of the tracks are carried out. Other records, such as single or plural footprints, distance between footprints, the width of footprints, and description of footprints such as stacked footprints, and others.

Identification of feces is measured in the form of feces (bolus, shaped like a paste, etc.), if it is a bolus then count the number of the bolus, the length of the feces, the largest bolus width, age of feces, and composition of feces. In addition, it is also possible to find footprints around the feces (Raharyono and Paripurno 2001). The composition of feces such as hair and teeth of prey is identified with the help of key informants (hunters) who know well about animals.

Scratches, especially the scratches of large cats are traced by examining the trees near the path. If you find scratches in a tree, various measurements are taken such as the length of the scratch, the distance between the scratches, the height of the scratches from the ground, the height of the first branch, and the scratch pattern. Scratches must be observed carefully. On the scratches, it is possible to find nails and leg hair left behind, especially in tree bark fibers. Nail can usually be found at the end of scratches and snagging. Hairs that left behind when doing a scratching can be found along the edge of the scratches or right-left area of the wound that is often scratched by the animal (Raharyono and Paripurno 2001). Around the scratching, trace if there are footprints or scratches on the ground.

Nests are traced to holes in the ground, holes in dead trees, cavities under dead trees, and holes under rocks (Wirdateti 2013). Nest searching can also be done at rock holes at the edge of the river. Active or inactive nests are identified through the age of feces, tracks, leftover, and the presence of spiderwebs. The active nest is measured by the length, width, and depth of the nest.

\section{Direct observation}

Survey was conducted to find arboreal mammals in the morning (06.00 a.m. - 11.00 a.m), in the evening (03.00 p.m. - 06.00 p.m.) and at night (07.00 p.m. - 10.00 p.m.) for nocturnal mammals. Observations conducted on the following transects on the path with modified transect width adjusting to the field conditions, and pausing every 10 minutes at the optimum speed of $1 \mathrm{~km} / \mathrm{h}$ (Struhsaker et al. 1981). Signs of the mammals' existence that need to be considered include movement of tree branches and sounds. If animals are found, record the number of groups and individuals in each group, and the number of sexes in the group.

\section{Camera trapping}

Camera trap installation is done to optimize the observation time for 24 hours. The installation period of at least 2 weeks using 16 camera trap units. Two units are programmed to capture images in hybrid mode (photos and videos), others in the program in photo mode. Camera trap with the hybrid mode is set to be able to capture videos of animals with a duration of 10 seconds, while the photo mode is set to be able to capture images of animals with a duration of 1 second. 
The location of the camera trap installation was chosen from the location recommended by the local community, previous research, and based on the presence of signs to increase the chances of mammalian encounters. Installation of camera traps was not carried out at the 15 sampling locations and each station is only installed in 1 unit and not installed simultaneously. Camera traps are mounted on tree trunks with an average height of $30-40 \mathrm{~cm}$ above the ground and facing a path with a distance of about $2.5-3 \mathrm{~m}$ (Ancrenaz et al. 2012; Ario 2007; Rowcliffe 2008).

\section{Collapsible trap}

Collapsible traps are used for small mammals, such as collapsible Sherman trap and collapsible wire traps. For most terrestrial small mammals, Sherman's live trap has become a foldable, very portable and efficient trap of choice (Hoffmann et al. 2010). The number of Sherman trap and wire trap is 15 traps with a total of 30 traps. Trap installation was conducted for two days at the determined sampling location. The placement of the trap was not carried out at all sampling sites due to limited time and surveyor personnel, only carried out on several sampling sites, including Curug Walet, Cilengkong, Cigintung, Ciawitali, and Cibayawak. The bait used was peanut butter which had been mixed with oats and wrapped in gauze. According to Hoffmann (2010), standard bait among many mammalogists is oatmeal flavored with peanut butter.

For inventories of small terrestrial mammals, the easiest approach is to place traps at equal intervals along a line. Spacing distances are a function of habitat complexity. Traps in more complex habitats should be more closely placed (Hoffmann et al. 2010). We recommend that a trapline ideally be about $150 \mathrm{~m}$ long, with traps placed every 10 to $15 \mathrm{~m}$ (Muhlenberg 1993 in Hoffmann et al. 2010; Jones et al. 1996), but this design has to be adapted to the respective habitat conditions and target species. Whatever the spacing, to increase the trap success, traps should be placed at habitat features (e.g. log, rocks, tree, runways, burrows, bush clusters) as long as the point (Hoffmann et al. 2010). We recommend placing two traps at every station to reduce the saturation of traps by very abundant species. This practice increases the chance of trapping animals that are less active, less attracted to traps (Drickamer 1987). Each trap station should have at least one Sherman trap, which can be combined with any other trap type available (Corbet and Harris 1990).

\section{Data analysis}

Analysis of qualitative data must consider the consistency of two perspectives, namely the perspective of the informant (emic) and the analysis of the researcher (ethics). In addition, when collecting interview results, researchers must always be able to check the validity of the data (Iskandar 2012). Qualitative data were analyzed crosschecking, summarizing, synthesizing, and narrative account sequence (Newing et al. 2011).

Animals caught during camera trap installation period were identified using a guidebook by Francis (2001). The identification of the footprint was identified using guidebooks by van Strien (1983), Atmoko et al. (2012), and Payne and Francis (2000).

\section{RESULTS AND DISCUSSION}

\section{Mammalian diversity}

Mammals found in Cisokan are 26 species (see Table 2). Based on the sampling sites, mammals tend to be concentrated in the Batu Nagok, Japarana, and Curug Walet blocks which are dominated by natural forest land cover, so it is assumed that mammals use natural forests as their habitat. In addition, these three locations are adjacent to the river as fulfillment of water sources, including the Cisokan River and Cirumamis River. Primates are often found on the riverbank. These locations are far from settlements even though there is still agricultural activity around natural forests. Other blocks such as Cilengkong, Pasir Taman, Cigintung, and Ciawitali are also found in mammals with land cover types dominated by production forests or agroforestry or Perhutani forests. The diversity of crops cultivated between perennials and agricultural crops allows for a longer food and energy chain. This condition will further support the creation of high biodiversity (Biodiversity). Agroforestry that has been arranged with high species diversity and good canopy composition can be a habitat for several species, such as primates, bears, and terrestrial mammals (Widiyanto 2013).

Several species always found in various types of land cover, such as natural forests, production forests, shrubs, rice fields, and agroforestry, including Javan Leopard and Wild Boar. This shows that these species have a high tolerance level for environmental changes. In addition, predator-prey relationships occur where leopards follow the presence of wild boar.

Some species of mammals found have Critically Endangered status by IUCN (2018) and Appendix I by CITES (2018), including Javan Leopard (Panthera pardus melas), Pangolin (Manis javanica), and Slow Loris (Nycticebus javanicus). Javan leopard is more commonly found in natural forests than other land covers, which is assumed that Javan leopard uses natural forests to meet their daily needs The main habitat for Javan leopard consists of heavily vegetated forests that are difficult for humans to access, and also the areas have steep topography (> $40 \%$ slope) and remote areas such as deep valleys or high hills that are difficult to reach. Similarly, African leopard prefers thick bushes in rocky environments and riverside forests as their main habitat. Leopards are particularly fond of areas that have trees for shelter and lurking activities as they are strong climbers (Gunawan et al. 2012). Besides being found in natural forests, leopards in Cisokan are also found in production forests - pine forests where there are many human activities and planting coffee plants (Shanida et al. 2018). According to Gunawan et al. (2012), the Javan leopard does not only use pine forests exclusively as its main habitat, but it also uses other types of vegetation for its daily activities, even it uses caves, rocky outcrops, and grooves or dried rivers as its shelter. 
Table 2. Jenis-jenis mammalia di Cisokan, West Java, Indonesia

\begin{tabular}{|c|c|c|c|c|c|c|c|}
\hline \multirow{2}{*}{ Species } & \multirow{2}{*}{ English name } & \multirow{2}{*}{\multicolumn{2}{|c|}{ Cover land types Sampling sites }} & \multicolumn{3}{|c|}{ Protected animal status } & \multirow{2}{*}{ Data types } \\
\hline & & & & RI & IUCN & CITES & \\
\hline \multicolumn{8}{|l|}{ Artiodactyla } \\
\hline \multicolumn{8}{|l|}{ Suidae } \\
\hline Sus scrofa (Linnaeus, 1758) & Wild Boar & \multicolumn{5}{|c|}{$\mathrm{Ag}, \mathrm{Nf}, \mathrm{Rf}, \mathrm{Sc}, \mathrm{Pf} 1,2,3,5,6,7,8,9,10,11,12,13,15$} & $\mathrm{CT}, \mathrm{Tr}$ \\
\hline \multicolumn{8}{|l|}{ Tragulidae } \\
\hline Tragulus javanicus (Osbeck, 1765) & Lesser Mouse-Deer & Sh, Ag & $8,9,12,13$ & $\checkmark$ & & & $\mathrm{CT}, \mathrm{I}, \mathrm{Tr}, \mathrm{Fe}$ \\
\hline \multicolumn{8}{|l|}{ Carnivore } \\
\hline \multicolumn{8}{|l|}{ Mustelidae } \\
\hline Aonyx cinerea (Illiger, 1815) & Oriental Small-clawed Otter & $\mathrm{Ri}, \mathrm{Rf}, \mathrm{Se}, \mathrm{Ag}$ & $5,11,14$ & & VU & II & $\mathrm{CT}, \mathrm{I}, \mathrm{Tr}, \mathrm{Fe}, \mathrm{Ne}$ \\
\hline \multicolumn{8}{|l|}{ Viverridae } \\
\hline Paradoxurus hermaphroditus (Pallas, 1777) & Common Palm Civet & $\mathrm{Ga}, \mathrm{Ag}, \mathrm{Nf}$ & $7,8,9,10,11,12,13,15$ & & & III & $\mathrm{DE}, \mathrm{CT}, \mathrm{Fe}$ \\
\hline Vivericula indica (Desmarest, 1817) & Oriental Civet & $\mathrm{Ga}, \mathrm{Ag}$ & 11 & & & III & $\mathrm{DE}$ \\
\hline Paguma larvata (C.E.H. Smith, 1827) & Masked palm civet & $\mathrm{Ag}$ & 8 & & & & $\mathrm{CT}$ \\
\hline \multicolumn{8}{|l|}{ Herpestidae } \\
\hline Herpestes javanicus (E. Geoffroy Saint-Hilaire 1818) & Small Asian Mongoose & Sh & $11,14,15$ & & & III & $\mathrm{CT}, \mathrm{Fe}$ \\
\hline \multicolumn{8}{|l|}{ Felidae } \\
\hline Prionailurus bengalensis (Kerr, 1792) & Leopard Cat & Rf, Ri, Nf, Pf & $1,7,9,10,11,12,13,14$ & $\checkmark$ & & II & $\mathrm{DE}, \mathrm{CT}, \mathrm{I}, \mathrm{Tr}, \mathrm{Fe}$ \\
\hline Panthera pardus melas (Cuvier, 1809) & Javan Leopard & \multicolumn{2}{|c|}{ Nf, Pf, Sh, Rf, Ag 6, 8, 9, 12, 13} & $\checkmark$ & $\mathrm{CR}$ & I & $\mathrm{CT}, \mathrm{I}, \mathrm{Tr}, \mathrm{Fe}$ \\
\hline \multicolumn{8}{|l|}{ Pholidota } \\
\hline \multicolumn{8}{|l|}{ Manidae } \\
\hline Manis javanica (Desmarest, 1822) & Pangolin & Sh, Ag, Nf, Pf & $6,8,12$ & $\checkmark$ & $\mathrm{CR}$ & I & CT, I, Lo, Tr \\
\hline \multicolumn{8}{|l|}{ Primate } \\
\hline \multicolumn{8}{|l|}{ Cercopithecidae } \\
\hline Macaca fascicularis (Raffles, 1821) & Long-tailed Macaque & $\mathrm{Ag}, \mathrm{Nf}, \mathrm{Ri}$ & $4,6,7,8,9,10,11,12,13,14,15$ & & & II & $\mathrm{DE}, \mathrm{CT}$ \\
\hline Presbytis comata (Desmarest, 1822) & Grizzled Leaf Monkey & $\mathrm{Ag}, \mathrm{Nf}, \mathrm{Sh}$ & $4,6,7,8,10,11,12,14,15$ & $\checkmark$ & EN & II & DE, I \\
\hline Trachypithecus auratus (É. Geoffroy Saint-Hilaire, 1812) & Javan Langur & $\mathrm{Ag}, \mathrm{Nf}$ & $4,5,6,7,8,9,10,11,13,14,15$ & $\checkmark$ & VU & II & DE, I \\
\hline \multicolumn{8}{|l|}{ Hylobatidae } \\
\hline $\begin{array}{l}\text { Hylobates moloch ( Audebert, 1798) } \\
\text { Lorisidae }\end{array}$ & Javan Gibbon & $\mathrm{Nf}$ & $7,8,9,10,11$ & $\checkmark$ & EN & I & DE, I \\
\hline Nycticebus javanicus (Boddaert, 1785) & Slow loris & $\mathrm{Ag}, \mathrm{Se}, \mathrm{Sh}$ & $1,2,3,4,5,6,7,11,14$ & $\checkmark$ & $\mathrm{CR}$ & I & $\mathrm{DE}$ \\
\hline \multicolumn{8}{|l|}{ Rodentia } \\
\hline \multicolumn{8}{|l|}{ Sciuridae } \\
\hline Sundasciurus lowii (Thomas, 1892) & Squirrel & Pf & $7,11,14$ & & & & DE \\
\hline Callosciurus nigrovittatus ( Horsfield, 1824) & Black-striped squirrel & Pf & $9,11,12,13,14,15$ & & & & $\mathrm{DE}$ \\
\hline Callosciurus notatus (Boddaert, 1785) & Plantain Squirrel & Pf & $7,11,12,14$ & & & & $\mathrm{DE}$ \\
\hline Ratufa bicolor (Sparrman, 1778) & Giant Squirrel & Pf & 13 & $\checkmark$ & NT & II & $\mathrm{DE}$ \\
\hline
\end{tabular}




\begin{tabular}{|c|c|c|c|c|c|c|}
\hline \multicolumn{7}{|l|}{ Muridae } \\
\hline Rattus argentiventer (Robinson and Kloss, 1916) & Ricefield Rat & $\mathrm{Rf}$ & 13 & & & MT \\
\hline \multicolumn{7}{|l|}{ Hystricidae } \\
\hline Hystrix javanica (F. Cuvier, 1823) & Javan Porcupine & Sh & $5,8,9$ & $\checkmark$ & & CT, Th, Lo \\
\hline \multicolumn{7}{|l|}{ Sciuridae } \\
\hline Lariscus insignis (F. Cuvier, 1821) & Three-striped ground squirrel & If & $11,12,14,15$ & & & CT \\
\hline Petinomys sp. (Thomas, 1908) & Flying Squirrel & $\mathrm{Pf}$ & 13 & & & $\mathrm{DE}$ \\
\hline Soricidae & & & & & & \\
\hline Suncus murinus (Linnaeus, 1766) & Asian Musk Shrew & Sh & 15 & & & $\mathrm{DE}$ \\
\hline \multicolumn{7}{|l|}{ Scandentia } \\
\hline \multicolumn{7}{|l|}{ Tupaiidae } \\
\hline Tupaia tana (Raffles, 1821) & Javan Treeshrew & Sh, Nf & 12 & & & $\mathrm{CT}$ \\
\hline Tupaia javanica (Horsfield, 1822) & Large Treeshrew & $\mathrm{Nf}$ & 15 & & II & $\mathrm{DE}$ \\
\hline
\end{tabular}

\section{Note:}

Source: Primary Data (2017), IUCN (2018), CITES (2018), and Regulation of the Minister of Environment and Forestry of the Republic of Indonesia (MoEF 2018)

Protected animal status: RI: Regulation of the Minister of Environment and Forestry of the Republic of Indonesia No. P.20 (No. P.20/MENLHK/SETJEN/KUM.1/6/2018) on species of Protected Plants and Animals, IUCN : International Union for Conservation of Nature; CR: Critically Endangered; EN: Endangered; NT: Near Threatened; VU: Vulnerable; CITES: Convention on International Trade in Endangered Species; I: Appendix I; II: Appendix II; III: Appendix III

Data types: DE: Direct Encounter, I: Interview, CT: Camera trap installation, MT: Collapsible trap, Tr: Tracks, Fe: Feces, Ne: Nest, Ha: Hair, Sct: Scratch, Scp: Scrape, Lo: Leftover, Th: Thorn Land cover types: Nf: Natural forest, Ri: River, Se: Settlement, Pf: Production forest, Rf: Rice field, Sc: Swidden cultivation, Ga: Garden, Ag: Mixed garden/ talun, Sh: Shrub

Sampling sites: 1: Datarmala, 2: Cipateungteung Atas, 3: Cipateungteung, 4: Curug Panganten, 5: Puncak Haur, 6: Pasir Nangka, 7: Cilengkong, 8: Batu Nagok, 9: Japarana, 10: Curug Cirumamis, 11: Curug Walet, 12: Pasir Taman, 13: Cigintung, 14: Ciawitali, 15: Cibayawak 
This shows that the leopard's home range overlaps with human land, so it has the chance of a human-leopard conflict. It needs to be studied further about the potential for human-leopard conflict in Cisokan based on threats and disturbances that affect mammals, especially leopards that are endangered.

Another species, Slow Loris, also has the potential for conflict with humans, as seen from its existence found in settlements, plantations, and agroforestry. According to Withanigsih (2019) that the local people living around the habitat of the Javan slow loris have high-intensity activities in the location of the habitat, so the possibility of damage to the habitat, as well as the opportunity to have direct contact with these animals, is also high. Therefore, local people play a very important role in direct protection, by not hunting or destroying their habitat.

Pangolins are commonly found in shrubs, agroforestry, natural forests, and production forests. Pangolins live in more than one habitat such as primary forest, secondary forest, event in plantation area of rubber, palm oil, or even in open spaces near human settlement areas (Lekagul and McNeely 1977; Davies and Payne 1982; Nowak 1999). In other areas in Indonesia like in Tanggamus and Lampung Barat Regencies, Pangolin was found in the production forest and secondary forest (Wirdateti et al. 2013).

In Cisokan, threats to Pangolin's existence continue to occur, such as hunting, trading, and land clearing for agriculture. Human activity in land cultivation might cause disturbance to Pangolins and led to the Pangolin's inability for nesting in the disturbed site (Withaningsih et al. 2018). Pangolin is a sensitive wild animal reacting to human activity. They tend to make their nests/burrows at least $1000 \mathrm{~m}$ from the disturbance sources. This is because Pangolins cannot adapt well to a noisy situation. The noise coming from other animal or livestock and human voices would interrupt Pangolin activity and mostly would scare them off resulting in stress for the Pangolin $(\mathrm{Wu}$ et al. 2003; Sawitri et al. 2012).

\section{Comparison of studies in Cisokan}

Within 10 years (2007-2017) several species were always found in each of their studies, such as Wild Boar, Javan leopard, Pangolin, Javan Gibbon, etc (see Table 3). This shows that the habitat in Cisokan can still fulfill its needs. In addition, as discussed earlier, the source of leopard's prey is always available every year as evidenced by the discovery of wild boar every year of study. The other leopard's prey, such as long-tailed Macaque, Javan Langur, and Grizzled Leaf Monkey also found in every year of studies.

However, the assumptions that habitat in Cisokan can still fulfil their needs do not indicate that there are no threats and disturbances to the habitat and mammals, so it needs to be studied further about the characteristics of mammalian habitats in Cisokan and the threats and disturbances that affect mammals in Cisokan. Endangered species such as Javan Leopard and Pangolin are always found every year of their studies but need to be studied further the condition of the population of these species, so it is necessary to do wildlife management in Cisokan.
Table 3. Comparison of studies in Cisokan, West Java, Indonesia

\begin{tabular}{lc}
\hline Species & Studies in Cisokan \\
& 20072009201220142017 \\
\hline
\end{tabular}

\section{Artiodactyla \\ Suidae}

Sus scrofa (Linnaeus, 1758)

Tragulidae

Tragulus javanicus (Osbeck, 1765)

Carnivore

Felidae

Panthera pardus melas (Cuvier, 1809) +++++

Prionailurus bengalensis (Kerr, 1792)

Herpestidae

Herpestes javanicus (E. Geoffroy

Saint-Hilaire, 1818)

Mustelidae

Aonyx cinerea (Illiger, 1815)

Viverridae

Arctictis binturong (Raffles, 1821)

Paguma larvata (Smith, 1827)

Paradoxurus hermaphroditus

(Pallas, 1777)

Viverricula indica (E. Geoffroy

Saint-Hilaire, 1803)

Eulipotyphla

Soricidae

Suncus murinus (Linnaeus, 1758)

Pholidota

Manidae

Manis javanica (Desmarest, 1822) ++++

Primate

Cercopithecidae

Macaca fascicularis (Raffles, 1821) $++\quad+\quad+\quad+$

$\begin{array}{lllllll}\text { Presbytis comata (Desmaret, 1822) } & + & + & + & + & + \\ \text { Trachypithecus auratus }(\text { E. } & + & + & + & + & +\end{array}$

Geoffroy, 1822)

Hylobatidae

Hylobates moloch (Audebert, 1798)

Lorisidae

Nycticebus javanicus (E.Geoffroy, 1812

Rodentia

Hystricidae

Hystrix javanica (Cuvier, 1823)

Hystrix brachyura (Linnaeus, 1758)

Sciuridae

Callosciurus nigrovittatus

(Horsfield, 1823)

Callosciurus notatus (Boddaert, 1785)

Lariscus insignis (Cuvier, 1821)

Petinomys sp. (Thomas, 1908)

Ratufa bicolor (Sparman, 1778)

Sundasciurus lowii (Thomas, 1892)

Muridae

Rattus argentiventer (Robinson

and Kloss, 1916)

Scandentia

Tupaiidae

Tupaia javanica (Horsfield, 1822)

Tupaia tana (Raffles, 1821)

Total

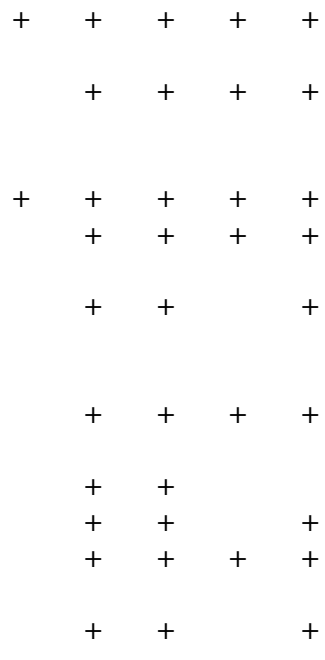

\footnotetext{
Sources: ANDAL-PT. PLN (2007), Rahmat (2009), LIPI (2012),

UNPAD (2014b), Primary data (2017)
} 
In conclusion, mammalian diversity in the Cisokan forest patched is found in 26 species and among them are endangered species, such as Javan Leopard, Pangolin, and Slow Loris. These three species occupy diverse land cover from natural forest to human lands, such as production forests, settlements, rice fields, and agroforestry or mixed gardens. The existence of these species on human land has the potential for human-wildlife conflict, so it needs to be studied further in wildlife management in Cisokan.

\section{ACKNOWLEDGEMENTS}

We would like to thanks the manjemant of Cisokan Hydropower, Erick Meijaard, and Program of Environmental Science, Padjadjaran University, Bandung that have supported this research. Thank you also to the research team and observer of Biodiversity Management Plan (BMP) 2017.

\section{REFERENCES}

Albuquerque UP, da Cunha LVFC, de Lucena RFP. 2014. Methods and techniques in ethnobiology. Springer, New York.

Ancrenaz M, Andrew JH, Joanna R, Rahel S, Andreas W. 2010 Handbook for wildlife monitoring using camera-traps. BBEC Publication. Malaysia.

ANDAL-PT. PLN. 2007. PLTA Upper Cisokan Pumped Storage in West Java.. PT. PLN (Persero), Bandung. [Indonesian]

Ario A. 2007. Javan leopard (Panthera pardus melas) among human activities: preliminary assessment on the carrying capacity of Gunung Salak Forest Area, Mount Halimun-Salak National Park. Conservation International Indonesia. Bogor. [Indonesia]

Atmoko SSU, Rifqi MA, Nisam G. 2012. The field guide of introducing of mammals and birds protected in Sumatera and Kalimantan. FORINA and USAID. Bogor. [Indonesian]

CITES. 2018. Checklist of CITES Species. http://checklist.cites.org/\#/en Accessed on September 12, 2018.

Corbet GB, Harris S. 1990. The Handbook of British Mammals. $3^{\text {rd }}$ ed Blackwell Scientific Publications, Oxford.

Davies G, Payne J. 1982. A Faunal survey of Sabah.WWF Malaysia, Kuala Lumpur.

Drickamer LC. 1987. Influence of time of day on captures of two species of Peromyscus in a New England deciduous forest. J Mammal 68: 702-703.

Fragoso JMV, Levi T, Luiz FBO, Jeffrey BL, Overman H, Jane MR, Kirsten MS. 2016. Line transect surveys undetected terrestria mammals: implication for the sustainability of subsistence hunting. PLoS One 11 (4): DOI: 10.1371/journal.pone.0152659.

Francis CM. 2001. A photographic guide to mammals of South-east Asia: including Thailand, Malaysia, Singapore, Myanmar, Laos, Vietnam, Cambodia, Java, Sumatra, Bali, and Borneo. Ralph Curtis Publishing. New Holland.

Gunawan H, Prasetyo LB, Mardiastuti A, Kartono AP. 2012. Habitat of Javan Leopard (Panthera pardus melas Cuvier 1809) in pine plantation forest landscape. J For Res Nat Conserv 9 (1): 49-67. [Indonesian]

Hoffmann A, Jan Decher, Francesco Rovero, Juliane Schaer, Christian Voigt, Gudrun Wibbelt. 2010. Chapter 19: Field methods and techniques for monitoring mammals. In: Manual on Field Recording Techniques and Protocols for All Taxa Biodiversity Inventories and Monitoring. Abc Taxa Publisher. United Kingdom.

Iskandar J. 2012. Ethnobiological and sustainable development. Research Center for Public Policy and Territorial. Graha Ilmu Press. Sumedang. [Indonesian]

IUCN. 2018. The IUCN Red List of Threatened Species www.iucnredlist.org. Accessed on September 12, 2018

Jones C, Mcshea WJ, Conroy MJ, Kunz TH. 1996. Capturing mammals (Chapter 8). In: Wilson DE, Cole FR, Nichols JD, Rudran R, Foster MS. (eds.) Measuring and Monitoring Biological Diversity. Standard Methods for mammals. Smithsonian Institution. Washington, DC.
Lekagul B, McNeely JA. 1977. Mammals of Thailand. The Association for the Conservation of Wildlife. Bangkok.

LIPI. 2011. Thematic Study of Flora and Fauna in the Hydropower Project Area "Upper Cisokan Pumped Storage" West Java. Research Center for Biology, LIPI, Bogor. [Indonesian]

LIPI. 2012. A Study on the Flora and Fauna in the Project Area of HEPP Upper Cisokan Pumped Storage West Java. Research Center for Biology, LIPI, Bogor. [Indonesian]

Meijaard E, Pene Ferguson. 2014. Biodiversity management plan upper Cisokan pumped storage. Technical report. PT PLN (Persero) Development Master Unit - UIP VI and Padjadjaran University.

MoEF. 2018. Regulation of the Minister of Environment and Forestry of the Republic of Indonesia P.20/MENLHK/SETJEN/KUM.1/6/2018

Newing H, Eagle CM, Puri RK. 2011. Conducting research in conservation: a social science perspective. Routledge. London.

Nowak R. 1999. Walker's Mammals of the world. 6th ed. Johns Hopkins University Press. Baltimore.

Payne J, Francis CM. 2000. The field guide of mammalia in Kalimantan, Sabah, Sarawak, and Brunei Darussalam. Wildlife Conservation Society. Bogor.

Prasetyo LB, CI Wijaya, Y Setiawan. 2013. Spatial model approach for deforestation: case study in Java Island, Indonesia. Pages 1901-1912. Geographic Information Systems: Concepts, Methodologies, Tools, and Applications. IGI Global.

Raharyono D, Paripurno ET. 2001. Tiger Joint Companionship Natural. The Gibbon Foundation, Jakarta. [Indonesian].

Rahmat A. 2009. UCPSS Biodiversity Survey. Upper Cisokan Pumped Storage Power Project (UCPSS) Additional Environmental Studies 2009. PT. PLN (Persero), Jakarta. [Indonesian]

Rowcliffe JM, Field J, Turvey ST, Carbone C. 2008. Estimating animal density using camera traps without the need for individual recognition. J Appl Ecol 45: 1228 -1236.

Sawitri R, Bismark M, Takandjandji M. 2012. Pangolin (Manis javanica Desmarest, 1822) behaviour in captive breeding at Purwodadi, Deli Serdang, North Sumatra. Jurnal Penelitian Hutan dan Konservasi Alam 9 (3): 285-297. [Indonesian]

Shanida SS, Partasasmita P, Hudoso T. Parikesit, Febriato P, Meganatara EN. 2018. Short Communication: The existence of Javan Leopard (Panthera pardus melas Cuvier, 1809) in the non-conservation forest areas of Cisokan, Cianjur, West Java, Indonesia. Biodiversitas 19: 42-46.

Struhsaker TT, Eisenberg JF, Thorington Jr RW. 1981. Census Methods for Estimating Densities in Anonymous: Techniques for the Study of Primates Population Ecology. National Academy Press. Washington, DC.

Sulistyadi E. 2016. Characteristics of large mammals community in Bali Barat National Park (BBNP). Zoo Indonesia 25 (2): 142-159.

UNPAD. 2014a. Biodiversity Management Plan Upper Cisokan Pumped Storage. PT. PLN (Persero) Bandung \& PPSDAL-LPPM University of Padjadjaran, Bandung. [Indonesian]

UNPAD. 2014b. Supervision and Land Clearing Consultation Services for the Construction of the Access Road of Upper Cisokan Hydropower Plan STA 21.450-STA 25.350. PT. PLN (Persero) Bandung \& PPSDAL-LPPM University of Padjadjaran, Bandung

van Strien NJ. 1983. A guide to the tracks of mammals of Western Indonesia. School of Environmental. Conservation Management. Ciawi. [Indonesia]

Widiyanto Ary. 2013. Agroforestry and its role in maintaining hydrological function and conservation. Forestry Research and Development Agency, Jakarta.

Wirdateti, Yulianto, Semiadi G. 2013. Distribution and habitat of Sunda Pangolin (Manis javanica Desmarest, 1822) in the districts of Tanggamus and West Lampung, Lampung Province. Proceedings Seminar Nasional Biodiversitas 2: 181-186 [Indonesian]

Withaningsih S, Parikesit, Ayundari A, Prameswari G, Megantara EN, Husodo T. Distribution and habitat of Javan slow loris (Nycticebus javanicus É. Geoffroy, 1812) in non-conservation area. AIP Conference Proceedings 2019, 060006 (2018); DOI: $10.1063 / 1.5061915$

Withaningsih S, Noorahya F, Megantara EN, Parikesit, Husodo T. 2018. Nest existences and population of Pangolin (Manis javanica Desmarest, 1822) at the designated area of Cisokan Hydropower, West Java, Indonesia. Biodiversitas 19: 153-162.

Wu SB, Liu NF, Ma GZ, Xu ZR, Chen H. 2003. Habitat selection by Chinese Pangolin (Manis pentadactyla) in winter in Dawuling Natural Reserve. Mammalia 67: 493-501. 